\title{
НАНОГЕЛИ, СПОСОБНЫЕ К «ВЗРЫВНОМУ» ВЫСВОБОЖДЕНИЮ ЛЕКАРСТВЕННЫХ ВЕЩЕСТВ И МАЛЫХ ИНТЕРФЕРИРУЮЩИХ РНК
}

\author{
В.А. Коржиков-Влах ${ }^{1}$, М.А. Хазанова', Ю.М. Пилипенко', Т.Б. Тенникова' \\ ${ }^{1}$ Институт химии, Санкт-Петербургский государственный университет, \\ 198504, Россия, Санкт-Петербург, Университетский пр. 26.
}

DOI: 10.19163/MedChemRussia2021-2021-73

E-mail:v.korzhikov-vlakh@spbu.ru

Наногели представляют собой гидрогели субмикронного размера, состоящие из гидрофильных или амфифильных полимеров, которые сшиты в единую структуру посредством ковалентных или физических взаимодействий. При этом мягкость, гибкость, деформируемость и гидрофильность являются характерными свойствами наногелей, которые обуславливают их уникальное биораспределение. В течение длительного периода времени системы доставки лекарств были сконструированы таким образом, чтобы обеспечить замедленное высвобождение. Однако, пролонгированное высвобождение требуется не всегда. Например, быстрое высвобождение цитостатических препаратов в опухоль может повысить эффективность терапии. Кроме этого, внутриклеточная доставка малых интерферирующих РНК (миРНК) не подразумевает длительное высвобождение, но требует быстрого увеличения концентрации молекул в цитозоле [1].

В представляемой работе были получены наногели на основе метакрилатных производных хитозана и гепарина, образующих интерполиэлектролитный комплекс, который дополнительно сшивался кетальным линкером в присутствии дитиотреитола. Предварительно было установлено, что избыток гепарина дестабилизирует частицы наногеля, но быстрое сшивание линкером позволяет получать стабильные частицы с инкапсулированным цитостатиком и/или миРНК. Частицы наногеля стабильны и не склонны к быстрому высвобождению в средах с щелочными и нейтральными pH, но достаточно быстро высвобождают загруженные препараты в кислых средах (при pH менее 6.5). Разработанные системы были охарактеризованы с точки зрения размеров, морфологии, способности к проникновению внутрь клеток и цитотоксичности. Также была изучена способность систем подавлять экспрессию зелёного флуоресцентного белка.

Работа была поддержана грантом РНФ (соглашение № 19-73-10045)

\section{Литература}

[1] V. Korzhikov-Vlakh, T. Tennikova, In: Lavrentieva A., Pepelanova I., Seliktar D. (eds) Tunable Hydrogels. Advances in Biochemical Engineering/Biotechnology, Springer, Cham. 2021. Journal. 2008, 178., 99-146. 